\title{
Creating Enhanced Capacity for Local Economic Development (LED) through Collaborative Governance in South Africa
}

\author{
Richard Douglas Kamara \\ PhD Candidate, Stellenbosch University, South Africa
}

\begin{abstract}
The complexities of the twenty-first century have paved way for the emergence and proliferation of cross boundary collaboration in the lexicon of localised and territorial development. Collaborative governance is increasingly playing a vital role in addressing the multi-dimensional challenges of the contemporary era. This paper seeks to contextualise collaborative governance as a possible remedy that could help to salvage the incapacitated municipalities and be more resourceful in their developmental mandate of fostering localised territorial development.

In addition, the article discusses some of the contextual limitations of commonly applied state-led and civilpowered approaches to address socio-economic problems in municipalities. To constitute a resilient collaborative governance capable of improving system management and responsiveness to socio-economic issues in municipalities, the paper tends to shed light on the emergence of another type of approach, the hybridcentric collaborative approach. Given this scenario, what would be the specific roles and relationship between the state and non-state?
\end{abstract}

Keywords: collaborative governance, Local Economic Development (LED), capacity, stakeholders, resources.

\section{JEL Classification: F63, O10.}

\section{Introduction}

The paradigmatic shift in development approaches as exemplified by contemporary development discourses confer a prominent role on localised and territorial development, otherwise known as the Local Economic Development (LED). These approaches involve the devolution, the delegation and decentralisation of authority to lower level of government. Rodriguez-Pose (2008: 23) describes LED as an integrated approach to development rather than a "one size fits all" solution, with its core purpose being "to mobilise the local economic potential by bringing innovation to all its growth dimensions which range from infrastructure, to local Small and Medium Enterprises and their skills, to attracting foreign direct investment, fostering territorial competitiveness, strengthening local institutions, better management of the development process and internalising local resources". Bringing together local governments, the private sector and civil society in a search for the right LED formula allows the community to build from the 'inside-out', capitalizing on local assets rather than from the 'outside-in' relying on external interventions (ILO, 2008: 2, as cited in Rogerson, 2011: 11758). The LED is multi-dimensional in nature. The perceived outcomes in LED initiatives require the collective initiatives of the various key stakeholders to make and/or implement multi-jurisdictional decisions that cannot be addressed by unilateral action (Emerson, Nabatchi and Balogh, 2012) for the common good of the society. Thus, LED seek the collaborative efforts of local stakeholders to grow the local economies and improve the standard of living of the local people. To this end, the government introduced the Intergovernmental Relations Act of 2005 with the aim of institutionalising collaboration between and among the three tiers of government. However, the municipalities don't seem to be receiving adequate intergovernmental supports to foster both their developmental and statutory mandates, let alone from other LED stakeholders. Similarly, several other collaborative tools have been introduced to coordinate LED activities in municipalities. These tools were based fundamentally either on the state centred approach or civil society driven approach. These ranges from the Integrated Development Plan (IDP) to Participatory Appraisal for Competitive Advantage (PACA).

However, there are municipalities that are very successful and others that are not in LED and one wonders why? Despite the overwhelming proclaimed benefits of collaboration of multi-actors for local governance, the conditions required to ensure its efficacy are extremely difficult (Kaiser, 2011; Fedorowicz et al., 2007). As Huxham and Hilbert (2008: 48) correctly put it: partnering is notoriously difficult; success rates as low 
as 20 per cent are often quoted (Huxham and Hibbert, 2008: 48). Drawing from their own personal experiences, Huxham and Hilbert (2008: 48) argued that getting some sort of positive outcome was never completely straightforward. On this note, the author is quick to mention the imperativeness of having an ideal form of governance as evidenced in the governance structure of well constituted collaborative entity as one of the fundamental conditions required for collaboration to succeed. Therefore, the analytical questions that needs to be asked here are as follows: What specific form of collaborative governance can improve the efficacy and governance of LED in municipalities. In this form of governance, what would be the specific nature and role of the state, private sector and the civil society and as well as the relationship between the state, private sector and the civil society?

Thus, the paper tends to aggregate and review previous literature on collaborative governance by focussing on the two approaches of collaborative governance, namely, the state-centric approach and the civil society centred approach. The civil society centred approach is a shift from the orthodox top down state-led collaborative approach to one with less emphasis on government or private business leadership and more attention to integrating civil society actors into coordinated problem-solving oriented network. The paper goes further to shed more light on the emergence of yet another type of approach, the hybrid-powered collaborative approach whereby the horizontal collaboration of the civil society-led approach is promoted alongside with the traditional top-down facilitating command of the state and incorporating the private sector as a strategic partner for balanced local development.

Through an analysis of collaborations for social innovation, the paper tends to add novel contributions to the scholarships that seek to break an intellectual impasse which has developed in academic discourses over the ideal form of governance aimed at improving system management and responsiveness to major socioeconomic issues within the municipalities, primarily, between those who believe in civil society driven approach as a preferred vehicle to address societal problems, and those who believe that the state can do it all alone. To this end the author articulates in the paper, a hybrid-centred approach as an emerging paradigm in the lexicon of collaborations for local governance, whereby the private sector, the state and the civil society through their respective roles and responsibilities collectively develop a common agenda, in innovating and designing solutions to societal problems.

The paper is stratified into five sections. Whilst the first section forms the introduction/background of the paper, the second section presents the LED context in South Africa, whereby the background of LED and the various challenges confronting the operationalisation of LED in South Africa are being discussed. The IGRF as a capacity building tool is presented in section three. The author conceptualises in section four, collaborative governance for LED as a collective endeavour for multi stakeholders to evolve a common agenda to address societal development issues within the municipalities. Through the lenses of state and society-led perspectives, the author presents the discussions on an emerging hybrid-powered approach of collaborative governance and a hypothetical case of the approach in the same section four. Finally, the paper is drawn to a conclusion in section five.

\section{LED in South African contexts}

This aspect of the paper focuses on LED in South Africa with special reference to its background and challenges as presented in sub-headings 2.1 and 2.2.

\subsection{Background}

There are 278 municipalities in South Africa, comprising 8 metropolitans, 44 districts and 226 local municipalities. They all focussed on growing local economies and providing infrastructure and services. In the South African context, LED usually refers to actions initiated at the local level, typically by a combination of partners, to address socio-economic problems or to respond to economic opportunities (HSRC, 2003: 12). As pointed out by Patterson (2008: 1) Local economic development in South Africa is a post 1994 phenomenon. Under apartheid, South Africa had a distinct regional planning policy characterised by strong central government control which suppressed the emergence of LED initiatives in towns and cities of South Africa and lead to the erosion of local autonomy. In facilitating a response to the multi-faceted development challenges which the country faces, South Africa's African National Congress government has initiated a veritable battery of policies to promote reconciliation, decentralisation, local empowerment, participation and development at the local government level (Binns, Porter, Nel and Kyei, 2005: 27). 
According to Sections 152 (c) and 153 (a) of the constitution, local government must "promote social and economic development" and it must "structure and manage its administration, and budgeting and planning processes to give priority to the basic needs of the community, and to promote the social and economic development of the community" (RSA, 1996). Moreover, the South African constitution establishes "developmental local government" which implies that the LED agenda in the context of South Africa, unlike in other countries is neither voluntary nor just a local government initiative but a constitutional requirement (Hofisi, Mbeba, Maredza and Choga (2013: 539). To this end, Smith and Vawda (2003: 28) asserts that the idea of developmental local government (DLG) emerged from the fusion of the social interventionist goals of the Reconstruction and Development Programme (RDP) and the market-driven economic strategies of the Growth Employment and Redistribution policy (GEAR); the two main national policies of the postapartheid era for addressing economic growth and poverty eradication.

The (RDP) was a policy framework for integrated and coherent socio-economic progress and it sought to mobilise all the people of South Africa and the country's resources toward the final eradication of the results of apartheid (RSA, 1996). The GEAR on the other hand was a strategy for rebuilding and restructuring the economy of South Africa in keeping up with the goals set in the RDP (RSA, 1996). The objectives of GEAR were to provide basic services to the poor, to alleviate poverty, achieve economic growth, reduce national debt, stabilise inflation and give effect to the socio-economic rights in the Constitution (Visser, 2004; City of Cape Town, 2004: no pagination). GEAR did not completely depart from earlier government policy but committed government to accelerating aspects of existing policy, albeit with a very significant compromise to the neo-liberal policy (City of Cape, 2004: no pagination).

As contested by Gilbert (2002) neo-liberal ideas has been dominant within ANC, even before the adoption of RDP. The strategy of GEAR focussed on neo-liberal, free market economy whereby special attention was accorded to macroeconomic stabilization as well trade and financial liberation to foster economic growth, increased employment and reduce poverty. Given this strategy, the government implemented batteries of neo-liberal measures, such as fiscal austerity, deregulation, export oriented development and privatisation, culminating into a distinct withdrawal of the state and a transfer of competence to the private sector, whereby areas previously the competence of the state, such as State-Owned Enterprises (SOEs) were included under a capitalist mode of production (Narsiah, 2002:3)

To this end several institutional arrangements were instituted to facilitate closer ties with the private sector. In 1998, the municipal infrastructure investment unit was established to facilitate the inflow of private capital into the provision of basic services. Similarly, the same period under review, witnessed the emergence of the Municipal Systems Act, Municipal Structures Act and a host of enabling documents pertaining to publicprivate partnerships which created the enabling environment for an increasing role of the private sector in the provision of public services in South African municipalities. Thus, the country has played host to the proliferation of public services outsourcing and different concessions of Public-Private Partnership (PPP) schemes in South African municipalities. In addition, privatisation has been of wider scale throughout the country. Thus, Narsiah (2002: 7) lamented that these initiatives were powered under the cloak of blackempowerment and entrepreneurialism.

Regrettably, these so-called local partnerships were controlled by multi-national corporations. Thereby creating a situation that the Author would like to describe as adding salt to injury, whereby the level of poverty becomes deepened and a widened gap of inequality ensued. Put in differently, the implications were farreaching indeed as thousands of jobs were at stake amidst increasingly widening inequality and slow pace of addressing poverty and other dimensions of well-being in the society. This is being evidenced in the wide spread of protests and manifestations in black township in the country.

Therefore, the Accelerated Shared Growth Initiative of South Africa (ASGISA) was promulgated in 2005 with the aims of improving policy implementation and economic growth by dealing with the challenges of lack of skilled and committed staff in the public service, inadequate financial resources, corruption and mismanagement of funds and lack of people-driven development. The plan promised to increase the growth rate to an annual average of $6 \%$ by 2010 , and to halve unemployment and poverty by 2014 . As argued by Blumenfeld (2015) the failure of the ASGISA to stimulate faster growth created lack of credibility for this ambitious plan.

It's interesting to mention that the current South African neo-liberal economic strategy on growth and poverty are based on two strategy documents. In 2010, the South African government adopted yet another ambi- 
tious neo-liberal macro-economic strategy known as the New Growth path (NGP), followed by the National Development plan (NDP) established in 2013. The NDP was developed by the national planning commission in the presidency, while the NGP by economic cluster under the leadership of Minister for Economic Development Ephraim Patel. Whilst the aims of the NDP is to ensure that all South Africans attain a decent wellbeing through the elimination of poverty and reduction of inequality (NPC, 2011), the NGP is intended to facilitate a restructuring of the south African economy to improve its performance in terms of labour absorption as well as the composition and rate of growth (Economic Development Department, 2011).

As correctly argued by Hendriks (2012: no pagination) these two strategies articulate strong developmental orientation, but the mechanism they envisage for achieving them are quite distinct. As the NDP seek to reduce poverty, unemployment and inequality, the NGP tends to enhance growth and create employment. Arguably, it be seen that though both the NDP and the NGP are oriented to the establishment of a developmental state as the key to overcoming inequality, their ideologies are dichotomous. The NDP is preoccupied with state powered approach of driving change through state intervention, investment and societal transformation. The state disposition on NDP was articulately argued by Hendriks (2012: no pagination) that the NDP focuses on advancing the developmental state by relying heavily on public resources to achieve its goals of service delivery and typically making the market share of previously disadvantage people a top priority above sustainability, efficiency, and profitability (Consultancy Africa Intelligence, 2012). The NGP, on the other hand, supports a more flexible monetary policy to enhance domestic demand and recognises that investments in poverty reduction, job creation and economic growth need strong social commitment and partnerships and cannot rely solely on public resources (Hendriks, 2012). However, the NGP has its own wit ends.

According to economic analysts, the policy has been levelled some criticism just as its predecessor neoliberal economic policies, the GEAR and the ASGISA economic policies, neither of which made a significant impact on economic development in South Africa.

Undoubtedly the continued hunt for all encompassing development policy provides the impetus for the emergence of the developmental concept of local government. Building upon the strategies of the RDP, 'developmental local government' is charged amongst other things with the achievement of local economic development, whereby the local government is conferred with the onerous roles and responsibilities of creating enabling environment for job creations and boosting the local economy through the provision of business-friendly services, local procurement, investment promotion, support for small businesses and growth sectors (Binns, Porter, Nel, and Kyei, 2005: 28). Thus, LED strategies are adjudged as having key roles to play in the alleviation of poverty and reduction of inequality in post-apartheid South Africa (African National Congress 1994; Nel and Binns, 2002: 8).

Therefore, local economic development policy and practice has evolved significantly in the post-apartheid era in South Africa (Nel and Binns, 2001: 355). According to Moyo (2007: 222) many strategies have been developed and are already being implemented through many LED initiatives. The strategies are defined largely in terms of a market-approach with the private sector playing a key role and municipalities working as facilitators. Evidently, Nel and Rogerson (2005: 17) argues that municipalities are applying a range of interventions in their local areas, some of which are distinctively pro-growth in focus, while others have a clear pro-poor emphasis. For most municipalities, the initial LED practice was confined to small projects, many of which were survivalist type initiatives in the form of community economic development projects, the majority of which proved unsustainable once donor or public-sector funding disappeared, and with no real impact on poverty reduction (Cohen, 2010; Rogerson, 2010). Evidently, the Development Bank Southern Africa (2008: 2) records reveals that the focus of most municipal LED initiatives in South Africa has been on Micro-level projects with the result that LED "lost currency as an effective sustainable development tool. In addition, Hindson (2003: 4) argues that the results have generally been disappointing with capacity and resource constraints being the key hindrances in many local authority areas (Nel, 2001 as cited in Nel and Rogerson, 2003: 8)

\subsection{Challenges}

According to Rogerson (2010: 489) the limited success of LED projects with a welfare focus has undermined the credibility and significance attached to LED by many local authorities. In South Africa, national policies, as pursued by the Department of Provincial and Local Government (DPLG) and the Department of Trade and Industry (DTI), are based on conflicting paradigms and have been pulling in different directions. Whilst the pro-poor agenda of the DPLG seek to influence the allocative process to benefit the poor through 
investment in infrastructures and businesses which are likely to benefit the poor, the DTI is primarily seeking on how to make capital more productive to enhance economic prosperity. Most policy papers are characterised by this tension between those two paradigms and try to bridge these tensions in various ways (Patterson, 2008: 4). Although these two approaches are complementary, the key policy issue is of defining the weight and balance of support to be allocated between them (Lambshead, 2007, as cited in Rogerson, 2010: 312). Similarly, Hofisi, Mbeba, Maredza and Choga (2013: 593) also argue that the conceptualisation of LED is theoretically unclear and underdeveloped, thus this further erodes the capacity of municipalities to successfully conceptualise and implement strategies for LED.

It has been argued in most literatures (Hindson, 2003; Nel, 2001; Rogerson, 2010) that the disappointing LED results in South Africa can be attributable to resource and capacity constraints compounded by limited experience of local government in terms of promoting economic development. In addition, Rogerson (2010) identifies some of the strategic challenges bedevilling LED implementation in South Africa as: lack of capacity at local government level; lack of funding for LED; ineffective LED methodologies for planning; poor coordination of networks.

As Maserumele (2008: 440) had stated, contemporary studies show that most municipalities in South Africa do not fare well in their attempt to assert themselves as developmental local government. This limited perceived success of LED in South Africa has meant that its career path lacks credibility, with the consequence that it is associated with low-level staffing and high turnover, especially outside the larger metropolitan areas and cities. Therefore, the practice of LED in many municipalities becomes either a 'dumping ground' for ineffective officials or only a stepping stone for competent local government personnel because of LED's constrained career prospect (Rogerson, 2010).

Given the result on the empirical studies on municipalities' skill challenge for accelerated service delivery in South Africa, some scholars (Maserumule, 2008; Kanye, 2006; Davids and Esau, 2012), argue that municipalities in South Africa are generally in crisis which is a clear case of capacity gap and this impact on their ability to fulfil constitutional mandate in many respects. Thus, emerging as a contributing factor to the waves of service delivery protests in blacks and coloured townships in South Africa (Legassick, 2010, and Good Governance Learning Network, 2008: 84).

To this end Rogerson (2009) argue that municipalities are therefore faced with the challenges of developing the capacity required to improve its performance towards the achievement of its developmental mandate. To bridge capacity gaps, the South African government has introduced the Intergovernmental Relations Act (IGRA) of 2005, which provides a framework on how to shore up and build capacity at local level by institutionalising cooperative governance between and among the three tiers of government, namely, the National, provincial and local government.

\section{The Intergovernmental Relation Framework (IGRF) as a capacity building tool for LED}

Given the IGRF, various roles and responsibilities have been assigned to the national, provincial and district municipalities on matters of supporting and building capacity for local municipalities to carry out its constitutional mandate of service delivery and LED. The national government is to coordinate public policies and investment programme (Department of Planning and Local Government (DPLG), 2005). The provisions of the 2006 LED framework clarified that the function of national government was to assist and create the conditions for local action to emerge and grow (DPLG, 2006). The DPLG (now Cooperative Governance and Traditional Affairs) has a chief directorate dedicated to LED which affords support in the following activities in the development and review of national policy, strategy and guidelines on LED:

Providing direct and hands on support to provincial and local government in selected cases;

$>$ Management and Technical Support to Nodal Economic Development Planning;

$>$ Facilitating, coordinating and monitoring of donor programmes, and

$>$ Assisting on LED capacity building processes.

According to Patterson (2008: 16) through such interventions, the DPLG's role is to mobilise resources, local role-players and interest groups 'for the sake of achieving economic growth and creating jobs to reduce poverty.' 
The 2005 LED Policy Guidelines sets forth key roles and responsibilities for the provinces and local government. The role of provincial government is seen as follows:

To assume a coordination role and taking responsibility for resources allocated from national to provincial government and ensuring that these are correlated with the priorities of the various Integrated Development Plans (IDPs) of the municipalities.

$>$ To establish LED forums to carry out the work of the National LED Forum and establish dedicated LED units in provincial governments, and to assume a role in building the capacities of municipalities to undertake LED and in supporting them in its implementation.

Since 2000, new roles have emerged for District Municipalities. Section 83(3) of the Structures Act describes the developmental mandate of District Municipalities, in terms of four aspects: Firstly, ensuring district-wide integrated development planning; secondly, providing district-wide bulk services, thirdly, building the capacity of local municipalities, and lastly, promoting the equitable distribution of resources between local municipalities. Thus, the district municipality is charged with the responsibility of managing, coordinating, implementing and monitoring various capacity building within the District and across the local municipalities (Davis, 2006: 9). According to Atkinson, van der Watt and Fourie (2003: 4) the role of District Municipalities remains very unclear. It remains to be resolved which "tier" of municipal government (district or local) should be the primary developmental tier, and where the important policy decisions should be made. It is also not clear what staff should be located at what level. As contested by Atkinson, van der Watt and Fourie (2003: 6) there is no hard and fast distinction between district development issues and local development issues and there should be a fluid and flexible involvement by District Municipalities and Local Municipalities, with regards to the overlapping functions. Based on the premise of the IGRF, all the three spheres of government, national, provincial and the municipalities, should exercise their distinctive powers, roles and responsibilities within principles of interdependence and interrelatedness.

Remarkably, one of the overarching tenets that underpinned the intergovernmental relation framework is the types and modalities of supports that needs to be rendered to the municipalities by the national and the provincial government. However, the municipalities are not receiving the adequate intergovernmental supports to foster LED as found out in the study of Montingoe (2012: 216).

Furthermore, during the course of another debate held on the $26^{\text {th }}$ of August 2010 by the South African National Councils of Provinces titled: The role of the National Council of Provinces in Cooperative Governance and Intergovernmental relations: Unlocking the synergies for collective efforts, Nonzakazi Swartbooi, a representative from Kwazulu Natal province acknowledged that whilst a lot has been done to institutionalise co-operative governance through a framework of intergovernmental relations, the reality, however, is that there is a pressing need to ensure that one move beyond the legislative pronouncements (Swartbooi, 2010: no pagination). Stemming from the same debate, however, Pravin Gordhan, the Finance Minister of South Africa, emphasised the need for more active engagement from provinces and local government on economic matters, in particular the dynamics role provinces and municipalities can play in providing economic infrastructure and opportunities to entrepreneurs and unemployed youth (Gordhan, 2010: no pagination). Evidently, it could be deduced from the foregoing argument that though the IGRF has been developed to guide and propel the tiers of government in South Africa towards adopting the spirit of shared purpose and mutual trust to addressing socio-economic issues, 'there are still some implementation gaps that needs to be addressed. At juncture, the Author is quick to add that this framework articulates the interdependence and interrelatedness between and among the tiers of government in South Africa, without much clarity on the emerging synergic relationship between government, Private sector and the Civil Society Organisation that is desired for a stable localised economic development. This gap provides an impetus for the emergence of this paper.

Thus, the next section of this paper seeks to contextualise collaborative governance as an effective way of building collective and adaptive capacity that could help to improve the capacity of municipalities and makes make more resourceful in their developmental mandate of fostering localised territorial development. Therefore, the paper aggregates previous literature on Collaborative governance by focussing on the two approaches of collaborative governance, namely, the state centric approach and the civil society centred approach. 
In addition, the paper discusses some of the contextual limitations of both approaches in its effort to collectively address socio-economic problems in municipalities. To constitute a resilient collaborative governance capable of improving system management and responsiveness to socio-economic issues in municipalities, the author is prompted to shed more light on the emergence of yet another type of approach, the hybridcentric collaborative approach whereby the horizontal collaboration of the civil society-led approach is promoted alongside with the traditional top-down facilitating command of the state and incorporating the private sector as a strategic partner for balanced local development. Given this scenario, the question is: What would be the specific nature, role of the state, private sector and the civil society and as well as the relationship between the state, private sector and the civil society in the emerging hybrid approach?

The remainder of this paper is structured as follows: In the fourth section, the Author contextualise collaborative governance whereby the author provide a brief review of various antecedents' theoretical framework on collaborative governance in terms of how to build an adaptive capacity for LED by focussing on the two approaches of collaborative governance, namely, the state centric approach and the civil society centred approach. Thereafter, the section contextualise the advocated hybrid-powered approach of collaborative governance and the roles of the actors, namely, the State, Civil society organisation and the private sector. A case of good practice of cooperative governance in South Africa is being discussed in the section and a conclusion to the paper is drawn in section five.

\section{Contextualising collaborative governance for LED}

LED is concerned with local people working together to achieve sustainable economic growth that brings economic benefits and quality of life and improvements for all in the community (World Bank, 2003). According to Meyer (2015: 632) the potential dynamic driving force behind LED initiatives is partnership formation by local stakeholders. It has been argued that local developmental projects driven by local business and local communities have more chance to succeed than projects attempted by government alone. In the same token, Clarke and Moir (2014, as cited in Cloete, 2015: 4) echoed that economic development should be orchestrated as a partnership activity between public, private and institutional sectors, with substantial vertical and horizontal collaboration on the public side.

Thus, it can be argued that the evolving complex issues in development management in the twenty-first century have paved way for the proliferation of cross boundary collaboration, whereby multiple levels of government, NGOs, associations and clients work together in search for knowledge and solutions designed to solve problems that go beyond one organisation (Agranoff and Mcquire, 2003: 16).

According to Ansell and Gash (2008) Collaborative governance is described as the engagement of public agencies and non-state holders in collective decision making. The principal objective of collaborative governance is to build collective capacity (Agranoff, 2006) for multi-level or multi scalar stakeholders - private, civic/non-governmental and public sphere, through the process of deliberation (Fishkin, 2009; Innes and Booher, 2010) and principled negotiation (Fisher, Ury and Patton, 2011) to make and/or implement multijurisdictional decision that cannot be addressed by unilateral action (Emerson, Nabatchi and Balogh, 2012) or the common good of the society (Agbodzakey 2015; Edigheji, 2010; Zurba, 2014; Bingham and O' Leary, 2008; Emerson and Nabatchi, 2015). However, the theory and practice of collaborative governance for localised economy seems to be rudimentary in South Africa.

According to Cloete (2015: 14) the interaction among the traditional economic stakeholders in South Africa, namely, the government, private sector and labour, is historically adversarial and currently, private sector view government with increased suspicions and disillusionment.

In contextualizing collaborative governance for LED, the researcher is primarily concerned with the ability of the collaborative governance regime to produce adaptive capacity to adjust responses to changing contextual drivers and internal processes, and to allow for development along the stability domain, as well as having the ability to be transformed into new developmental pathway, in a sustainable way. To put simply, the ability to enhance capacities within municipalities to be more resourceful, efficient and sustainably delivery on their developmental mandates. Stemming from the urban and regional development perspectives, several scholars have conceptualised adaptive capacity as the ability of communities to withstand external shocks to their social infrastructure (Agder, 2000); the way in which people adapt to changing circumstances to sustain themselves through self-governing initiative (Katz, 2004); and the capacity of humans to anticipate change and influence future pathways (Omagano Shoola, 2016: online). 
Such adaptive capacity as mentioned in several literatures, can evolve as a result of the following benefits associated with collaborative/cooperative governance: improved and enhanced coordination of activities, better leverage and pooling of resources, increased social capital, enhanced conflict management, better knowledge management (including, translation and diffusion), increased risk sharing in policy experimentation (Agranoff, 2007; Agranof and Mcquire, 2003; Leach and Sabatier, 2005; Provan and Milward, 1995).

Thus, Dawley et al. (2010); Simmie and Martin (2010) as cited in Mackinnon and Derickson 2012: 261) echoed the imperativeness of regional institutions' role to foster adaptive capacity as an underpinning factor to the development of successful regions such as Cambridge. As correctly argued by Wolfe (2010: 145), 'Successful regions must be able to engage in strategic planning exercises that identify and cultivate their resources, undertake collaborative processes to plan and implement change and encourage a regional mindset that fosters growth. Therefore, the key theme in focus in this context is mostly on the importance of agency having the adaptive capacity and strategic leadership acumen in framing and responding to crises and challenges. However, the question is: Do the state organ alone has this adaptive capacity to respond to changes and uncertainties in the society?

Thus, the tasks of creating such adaptive capacity capable of improving the system management and responsiveness to major social and economic issues within the municipalities, is a process that requires the collective efforts of trio actors, namely, the state, private sector and the civil society organization. However, the ensuing questions are: Under this dispensation, what is the nature, the role and the relationship between and among the state, the private sector and the civil society organizations? What specific form of collaborative governance can improve the efficacy and governance of LED in municipalities?

In the past decade a number of alternative theoretical framework for collaboration have been proposed by different scholars: Design and Implementation of Cross-Sector Collaborations (Bryson, Crosby, and Stone, 2006); Collaboration Processes (Thomson and Perry, 2006); Collaborative Governance (Ansell and Gash, 2008); Managing within Networks (Agranoff, 2007); Collaborating to Manage (Agranoff, 2012), Modes of Network Governance (Provan and Kenis, 2008); Integrative framework for collaborative governance (Emerson, Nabatchi and Balogh, 2012) and Communicative Framework of Value in Cross-Sector Partnerships (Koschmann, Kuhn, and Pfarre, 2012). These frameworks have much in common, but they differ in important ways (Bryson, Crosby and Stone, 2015: 4). Collectively they show commonalities of collaborative governance in terms of portraying the various contextual matters present within the environment (system context) that could influence it outcomes; the dynamic collaborative process within the context that constitute the collaborative Governance regime and the desired outcomes emanating from the collaborative process capable of enhancing the capacity or capability of each and every parties to the collaborative governance regime to achieve a common purpose. As contained in the integrative framework of Emerson, Nabatchi and Balogh (2012), these contextual issues that influences collaboration level and outcomes include: Procedural and institutional arrangement in terms of the procedures and organisational structures required to manage the iterative reaction over time; the Leadership roles required either at the start of the collaboration or during the process of collaboration to steer it through to implementation (Bryson, Crosby, and Stone, 2006); the knowledge and the resources capacity acquired through resources leverage. As correctly argued by Agranoff (2008: 165), the term knowledge in this context refers to the social capital of shared knowledge that has been weighed, processed, and integrated with the values and judgments of all participants. Stemming from the application of these frameworks in practice as synthesised by the author, two overarching models evolves, namely, the state- centric model and the society-centric model (Clarke, 2016).

\section{State centric-model}

In state-centric models, the success of collaborative endeavours hinges on the state whereby the public managers are central to negotiating, initiating, and funding collaborative arrangements. The public managers are bestowed with the formal power and authority to deliberate, to reach consensus, to arbitrate conflicts, to set rules, and to commit state power, authority, and resources to joint action. According to Clarke (2016), with the absence of these acts, state-centric collaboratives would not exist. Having taken due cognisance of the pivotal role of the state towards the success of collaborative process in a state-centric model, in order to determine the ability of such collaborative to enhance the system management of development policies at local level, one is prompted to ask the following analytical questions: To what extent do these processes promote democratic accountability, deliberative capacity, or inclusive citizen participation? How do these processes shape the perception of the participants about the legitimacy of the government and its policy? To 
what degree do participants have true equality in terms of participation, power, and authority during the processes? The answers to these questions are not far- fetched. It has been evidently contested that these processes vary on many salient dimensions, including the degree to which they include the general public, promote genuine deliberation, foster relational or rational discourse and have a tangible outcome (Fung and Wright, 2001; Torres, 2003; Williamson, 2004; Bingham, Leary and Nabatchi, 2004). According to Coglianese, Kilmartin and Mendelson (2009) agencies tend to solicit public input through the notice-andcomment process of informal rulemaking, rather than through democratic deliberation. In addition, it can be argued that under state-centric configuration, the government's actions are severally challenged. Given the wide-ranging and potentially conflicting roles a government fulfils, as correctly argued by Yamak and Suer (2005) there is the possibility of significant ethical and practical problems that potentially undermines the government position as stakeholder in a collective endeavour. It has been argued that the political and institutional context in which state-led collaborative operates present as many difficulties as privileges. These amongst other things include capacity constraints, divergent policies and priorities and fiscal volatility. Similarly, Clarke (2016) contests that public officials operate in a context of over lapping jurisdictions whereby power is shared and with fragmented authority constrains by weak fiscal policy. As prospects for collaborative problem solving are constrained by these contextual limits on their formal powers, the author is prompted to ask: How can public administrators fulfil the mandate to engage citizens and stakeholders in ways that enhance the legitimacy of governance? What are the forms and best practices for citizens and stakeholders to participate in the local governance? The answer to these questions could be seen in the later part of the paper presented under the emerging hybrid-centric model of governance.

\section{Society-centric model}

The emergence of the society centred approach was enthusiastically heralded as a shift from the orthodox top down state-led collaborative approach to one with less emphasis on government or private business leadership and more attention to integrating civil society actors into coordinated problem-solving oriented network.

From the society-centred approach, collaborative governance is adjudged to be concerned with the role of civil society, the nature of civil society in terms of how it can be mobilized, structured and the relationship between civil society and the state.

As pointed out by Clarke (2016) in this approach, although government agencies and some businesses are often involved as partners, and often provide funding, they are unlikely to initiate or direct these societybased collaborative efforts. Clarke added that the society-centred collaborative is characterised with the involvement of multiplicity of cross-sectoral actor which articulates broad civic purposes or a common agenda, mobilize for joint work, and coordinate implementation of project-specific activities that cannot be achieved unilaterally by any one organization. It has been argued that collaborative endeavours powered by society-centric model often have very informal structure and functioning (Desse, 2012: 10) and in most cases tends to address social issues that rarely attain the agenda status of economic development prospects. Another drawback that has been levelled against this type of model could be seen considering transparency and accountability. According to Desse (2012: 10) the CSOs are not very transparent and accountable, especially when it comes to financial matters and internal transparency. To this end, the author is quick to emphasise here that transparency and accountability are so imperative to the efficiency and effectiveness of any collaborative endeavour, especially when it comes to the building of mutual trust

To this end, Cross (undated) as cited in Selmeczi (2015: 55) claim that the political concerns of the civic organizations ("the civics," as they are commonly referred to) prevent them from successfully partaking in community development as they fail to grasp the subtle dynamics operating in poor segments of the society.

Cross argued that although the civic now offers their services as development intermediaries, the civics are not suitable for instilling a common sense of nationality and internalised sense of order. This assertion seems to subject civic to a relegation bench as it tends to question the reputation and legitimacy of the civic organisation in its statutory roles of supporting poverty reduction by helping citizen and pressurizing government and state institutions for social accountability and responsiveness.

Similarly, Banulescu-Bogdan (2011) pointed out the problems of coordination, lack of political integration and institutionalization often faced by civil organisations. 
Following these backdrops, the continued search for a cut-edging approach remain unabated. This provides an impetus or the rationale for the author of this paper to advance the use of yet another type of approach called the Hybrid approach as discussed below.

\section{Hybrid-centred approach of Collaborative Governance: Roles of the State, CSO and the Private sector}

Stakeholders in the hybrid domain has the interest and the willingness to go beyond their conventional knowledge to identify sustainable solutions for social missions (Aoyama and Parthasarathy, 2017: no pagination).

The hybrid-centred approach of collaborative is a new paradigm shift from seeing governance as the exclusive sanctuary of the government or the civil society, but as an all-encompassing governance that incorporates the contributions of the civil society and the private sector alike. The principal characteristics of a wellfunctioning developmental state is a healthy relationship between the private sector, government and civil society. The performance efficiency of the trio is required to sustain balanced localised economic development (Essia, 2015). Stemming from the hybrid powered approach of collaborative governance, whilst the state maintains its orthodox roles of creating the enabling environment for the functioning of the entire systems, and all activities (Dohan, Doh and Raelin, 2014: 665; Buchholz and Rosenthal, 2004) the private sector generates jobs and income and the civil society facilitates sound service delivery and mobilises people and group to participate effectively in development. In addition, the civil society supports poverty reduction by helping the citizen to empower themselves and pressurizing government and the private sector institutions for local accountability and public finance management (Essia, 2015: 2). Given this scenario, the government cannot benefit from a special status or privileges enabling it to force the actors to conform to its expectations.

Therefore, the actors as contested by Dahan, Doh and Raelin, 2014: 665) are at liberty to treat the government just as well as any other of its stakeholders. Though governments can still play its advocating roles for other stakeholders (Friedman and Miles, 2002). Given the perspective of Donahue and Zeckhauser (2011: 32) collaboration is a system whereby the government relies on private actors whom it motivates, influences, and constrains, but does not fully control. This incomplete control is deliberately acknowledged as a prerequisite to high performance of collaborative endeavours. Interestingly, the role of the private sector on the host communities in this new approach is closely link with the state and non-state and can be seen through the lenses of corporate social responsibility (CSR) to measure their corporate performance.

In furtherance, strategic management underscores the importance of managers working with elected officials and the political environment, as well as with other external stakeholders, to develop and enact policy. Similarly, the proponents (Aoyama and Parthasarathy, 2016; Galli and Fishers, 2016) of hybrid powered governance seek for new governance processes that promotes increased collaboration among government, private sector, civil society, and citizens. The type of collaboration that enhance democratic decision making; and promote decisional legitimacy, consensus, citizen engagement, public dialogue, reasoned debate, higher decision quality, and fairness among an active and informed citizenry.

Imperatively, the hybrid approach is capable of evolving solutions that promote continued engagement and require joint responsibility for implementation, monitoring, and revision, unlike the traditional state centred and society centred approach that deny parties responsibility and encourage them to disengage after a single interaction. In addition, such desired collaboration promotes and maintain accountability for collective decisions; advance political equality while educating citizens; foster a better understanding of competing interests while contributing to citizens' moral development; and orient an atomized citizenry toward the collective action (Bingham, Nabatchi and Leary, 2004: 554).

Another important feature of a hybrid approach is the process of negotiation. Though there could be a certain degree of adversarialism of stakeholder's relationship due to their differing interests, interestingly, hybrid approach enhances a fundamental trade-off in values and objectives for mutual benefits. Thus, negotiation in a hybrid approach tend to occur among parties that need each other and cannot entirely impose their will onto the other, same as in the case of public-private partnerships (Akintoye et al., 2003; Dahan, Doh and Raelin, 2014: 667) and cross-sector collaborations (Eggers and Macmillian, 2013); Selsky and Parker, 2005). In terms of their decision making, the decision processes may vary from adopting an agenda to taking some action. However, decisions emerge because of shared learning experiences in which the product is the creative solution that emanates from the discussion (Bingham, Nabatchi and Leary, 2004: 549). Finally, the 
effective participation of the various actors should provide checks and balance against corruption and promote accountability and transparency of local official (Brillantes and Fernandez, 2011: 23). Actors in this type of approach are interdependence and accountable to each other. Stemming from this approach, some of the orthodox functions and responsibilities performed by the state to promote accountability may ultimately be performed by independent auditors, public interest groups, standard-setting organisation, and workplace and community group might oversee rule implementation and evaluate compliance (Freeman, 2011: 14).

It has been argued that the success of collaboration is a function of the system context within the environment and the dynamic process of the collaboration itself within the context. Stemming from the scope of this paper, the contextual factors presented here are confined to the resources required to support and reinforce the collaborative regime and as well as the legal framework present in the environment to promote collaboration. The parameters (process element) for the dynamic collaboration process are being curtailed to the participant/representation, process design and content of the collaborative process. To this end, the paper tends to present a normative framework on the roles of the various actors in a hybrid powered approach of collaboration as shown in Table 1 in the Appendix.

Given the table below, it reveals the universality of responsibility of all the actors in hybrid powered collaboration to provide the requisite resources to support the collaborative regime. These resources include but not limited to funds, time, technical knowledge and information. In formulating the contextual legal framework, the state is required to grant some discretions to the private sector and the civil society. However, under this scenario the state should neither be seen as an umpire or a pushover, rather, the trio actors needs to be involved in setting common agenda based on equal footings. Similarly, the roles of the various actors during the collaborative process are articulately reported in the table, all the actors in the collaboration takes full ownership and responsibility for selection of participants, as well as the process and content design of the collaboration process.

An additional column is added which tends to articulate the parameters that could be taken into consideration so as to enhance accountability among the various actors. As contained in the table, in order to promote responsiveness and accountability among the actors in terms of resources provision, there needs to be a mechanism in place for rewarding and incentivising actors for good performance.

In the same vein, there needs to be clarity of laws and regulation, institutional arrangements in place to enhance responsiveness and accountability. As it would be improper and derogatory for actors to be responsive and accountable to ambiguous laws and regulation, especially where there is lack of discernible institutional arrangements in place.

Lastly, it can be argued that the expertise of representatives in a collaborative process tends to infuse some sense of legitimacy and credibility into the deliberative process. Interestingly, such legitimacy and credibility goes a long way to promote mutual trust that could enhance responsiveness and accountability among the interdependent actors to each other.

An example of a good practice of Hybrid-centred Collaboration in South Africa (The Garden Route Film Office)

This section seeks to review a successful case of hybrid powered collaborative initiatives in South Africa, "The Garden Route Film Office".

This is a project created to facilitate and enhance the contribution of the Film industry to the economic growth of the region of Western Cape in South Africa. The project was designed to market the Garden Route and Kleine Karoo (a suburb town in Western Cape) with its inherent beauty and natural attractions and wide range of locations, as a tourism, but more specifically, film destination of choice. The South African Film Industry has seen film shoot since 2008, generating over R150 million dollars since 2003. This shows a huge potential for South Africa in the film industry that needs to be harnessed. The most recent examples of movie shoots in the Garden route includes: Klein Karoo (Movie); Hanna Hoekom (MovieTsitsikamma area); Knysna (movie); Hidden City (1992-1995's South African TV show in Hakerville) and the First Man (2016).

The Garden Route Film Office is a unique regional collaboration under the auspices of the South Cape Economic Partnership, a collaboration between local municipalities, business chambers and a broad range of regional Stakeholders. The South Cape Economic Partnership (SCEP) is an offshoot of the Economic De- 
velopment Partnership (EDP) initiative in Western Cape Province of South Africa. The EDP, an independent, multi- sector, non-profit, public benefit organisation was established in 2012 as a collaborative intermediary organisation with the overarching objective of creating and sustaining partnerships between economic stakeholders to create a resilience, competitive region capable of providing solutions to South Africa's socio-economic challenges. The organisation emerged following agreement between approximately 130 public, private, academic and civil society stakeholders in the regional economic delivery system (Economic Development Partnership n.d.)

The EDP work with national and provincial government, state-owned entities, municipalities, business association, civil society organisations and universities. The case study of EDP is viewed as an exemplified hybrid model of collaborative governance whereby the governing board membership of the organisation is composed of both public and private sector. As the governance structure permits local knowledge of business issues to direct the organisation's efforts, imperatively, the partnership benefits in various ways from the local knowledge provided by the business community through its representative on the board, without jeopardizing the increasing role of the civil organisation as key stakeholders working in conjunction with the state.

The EDP budget largely consist of funds derived from the government. However, the organization is striving towards reducing its reliance on public funding and increasing its financial support from the private sector. This could be achieved through, private sector sponsorships and corporate partnerships. Notably, the EDP has been involved in identifying and formulating new partnering methodologies, galvanising the relations between the various partners, and designing and sustaining enabling platform aimed at improving the system management and responsiveness to major socio-economic issues in the municipalities. As epitomised by the notable outcomes of the Garden Route film strategy, the EDP played a unique role in bringing together different stakeholders, the public sector, the private sector, academia and civil society to focus on specific local issues that had been identified as key drivers of economic growth in the municipalities. Thus, the unique advantage of having private sector representatives among the governing board of the organisation allows the EDP to be closely connected to the business community and its needs and can generate strong support for the organization's initiatives. In addition, the organisation disposition to private sector funding also provides the organization with increased access to resources and reduces reliance on public sector funding which ordinarily constrains the capacity of municipalities to delivered on its developmental roles.

\section{Conclusion}

The paper has presented the background of LED and cooperative governance in South Africa. Also presented along with the LED background, the issues of developmental local government as envisioned in the various neo-liberal economic approaches implemented by the ruling party in South Africa to redress the economic imbalances of the past and to propel the country's economy for growth. Extant literatures on collaborative governance were aggregated with a special focus on two models, namely, the state- centred model and the society-centred model of governance. Some of the constraints faced by both models were discussed in the paper. Following the shortcomings of the two models as discussed in the paper, the Author added to the voice of those scholars advocating for more all-inclusive, democratically deliberative and resilient new collaborative governance approach that encompasses the government, private sectors and the civil society. Finally, a successful case of a hybrid-centred model of governance was equally presented in the paper.

\section{References}

1. Agder, W. N. (2000). Social and ecological resilience: Are they related? Progress in Human Geography, 24, 347-364.

2. Afful-Koomson, T., and Owosu, A. K. (2013) Collaborative Governance in Extractive Industries in Africa. United Nations University Institute of Natural Resources in Africa (UNU-INRA), Ghana.

3. Agbodzakey, J. K. (2016) Quantitative evidence of Collaborative Governance of Broward and Beach Palm Counties HIV Health services planning councils in two different legislative cycles. International Journal of Current Advanced Research, 4(12), 520-530.

4. Agranoff, R. and McGuire, M. (2003) Collaborative Public Management: New Strategies for Local Governments. Washington, DC: Georgetown University Press. 
5. Agranoff, R. (2006) Inside collaborative networks: Ten lessons for public managers. Public Administration Review, 66, 56-65.

6. Agranoff, R. (2007). Managing within Networks: Adding Value to Public Organizations. Washington, DC: Georgetown University Press.

7. Agranoff, R. (2008) Collaboration for knowledge: Learning from public management networks. In Big Ideas in Collaborative Public Management, eds. L. B. Bingham and R. O'Leary, 162-194. Armonk, NY: M.E. Sharpe.

8. Agranoff, R. (2012). Collaborating to Manage: A Primer for the Public Sector. Washington, DC: Georgetown University Press.

9. Akintoye, A., Beck, M. and Hardcastle, C. (2003). Public-Private Partnerships: Managing Risks and Opportunities. Blackwell Science Ltd.

10. Ambrosio-Albala, M. and Delgado, M. (2008). Understanding rural areas dynamics from a complex perspective. An application of Prospective Structural Analysis. Paper prepared for presentation at the 12th EAAE Congress 'People, Food and Environments: Global Trends and European Strategies', Gent (Belgium), 26-29 August 2008.

11. ANC (African National Congress) (1994). The Reconstruction and Development Programme: A policy framework. Umanyano Publications, Johannesburg.

12. Ansell, C. and Gash, A. (2008) Collaborative governance in theory and practice. Journal of Public Administration Research and Theory, 18, 543-571.

13. Aoyama, Y. and Parthasarathy, B (2017). The rise of the Hybrid domain public domain. Collaborative for Social Innovation. Edgars Publishing. USA.

14. Atkinson, van der Watt and Fourie (2003). The Role of District Municipalities: Hologram Project. Final report, HSRC and Eden District Municipality.

15. Bingham, L. B. (2008). Legal frameworks for collaboration in governance and public management. In Big ideas in collaborative public management, L. B. and O'Leary, R., 247-269. Armonk, NY: M.E. Sharpe.

16. Bingham, L. B., and O’Leary, R. (2008). Big ideas in collaborative public management. Armonk, NY: M.E. Sharpe.

17. Bingham, L. B., O’Leary, R and Tina Nabatchi, T. (2005). The New Governance: Practices and Processes for Stakeholder and Citizen Participation in the Work of Government. Public Administration Review, 65(5), 547-558.

18. Binns, T., Kyei, P., Nel, E., \& Porter G. (2005). Decentralising poverty? Reflection on experience on decentralisation and the capacity to achieve local economic development in Ghana and South Africa. Africa Insight, 35(4), 21-31.

19. Blumenfeld, J. (2015) A hole digger's Guide to Redemption: Some reflection on South Africa's Longrunning Quest for Economic growth. Journal of the Helen Suzman Foundation, 75. Available at: file://C:/Users/Microlab/Downloads/4\%20A\%20Hole-digger2019s\%20Guide\%20to\%20Redemption\%20\%20J\%20Blumenfeld\%20(1).pdf. Accessed on 14 May, 2018.

20. Brillantes Jr., A. B., and Fernandez, M. T. (2011). Good Governance, Social Quality and Active Citizenship: Gawad Kalinga in Phillipines. The International Journal of Social Quality, 1(2), 19-30.

21. Bryson, J. M., and Crosby, B. C. (2008). Failing into cross-sector collaboration successfully. In Big ideas in collaborative public management, eds. L. B. Bingham and R. O'Leary, 55-78. Armonk, NY: M.E. Sharpe.

22. Bryson, J. M., Cosby, B. C., and Stone, M. M. (2015). Designing and Implementing Cross-Sector Collaborations: Needed and Challenging. Public Administration Review, $x x(\mathrm{xx})$, xx-xxv.

23. Bryson, J. M., Crosby, B. C. and Stone, M. M. (2006). The design and implementation of cross-sector collaborations: Propositions form the literature. Public Administration Review, 66, 44-55.

24. Buchholz, R. A., \& Rosenthal, S. B. (2004). Stakeholder theory and public policy: How governments matter. Journal of Business Ethics, 51(2), 143-153.

25. City of Cape Town (2004). City of Cape Town Smart City Strategy in South Africa.

26. Clark, G., and Moir, E. (2014). The Business of Cities. Foresight, UK Government Office for Science. In Cloete, E. A partnering approach to economic development at a sub-national level - A practitioner's perspective. Western Cape Economic Development Partnership. South Africa.

27. Clarke, S. E. (2016) Local Place-Based Collaborative Governance. Urban Affairs Review, 1-26.

28. Cloete, E. (2015). A partnering approach to economic development at a sub-national level - A practitioner's perspective. Western Cape Economic Development Partnership. South Africa. 
29. Cohen, D. (2010). Key issues in local economic development in South Africa and a potential role for SALGA. Pretoria: Paper submitted to Department of Cooperative Governance and Traditional Affairs.

30. Coglianese, C., Kilmartin, H., and Mendelson, E. (2009). Transparency and Public Participation in the Federal Rulemaking Process: Recommendations for the New Administration. George Washington Law Review, 77(4), 924-972. Available at: http://www.gwlr.org/wp-content/uploads/2012/08/77-4Coglianese.pdf. Accessed on 14 July 2017.

31. Consultancy Africa Intelligence (2012). Can South Africa be considered a developmental state? The New Growth Path and National Development Plan in Perspective.

32. Cross, S. (1992). From Anomie to Civil Society in South Africa. Reflection on Development Planning, as cited in Selmeczi, A. (2015). Haunted by the rebellion of the poor: Civil Society and the Racialised Problem of the (Non-) economic Subject. Faucault Studies, 20, 52-75.

33. Dahan, N. M., Doh, J. P. and Raelin, J. D. (2015). Pivoting the Role of Government in the Business and Society Interface: A Stakeholder Perspective. Journal of Business Ethics, 131, 665. doi:10.1007/s10551014-2297-2.

34. Dawley, S., Pike, A. and Tomaney, J. (2010). Towards the resilient region? Local Economy, 25, 650-667.

35. Donahue, J. D. and Zeckhauser, R. J. (2011). Collaborative Governance: Private Roles for Public Goals in Turbulent times. Princeton University Press. USA.

36. Davids, B and Esau, M. (2012). The prevailing Skill crisis in South Africa: An Exploration of the Skills Development Strategy of the City of Cape Town. Journal of Developing Societies, 28(1), 81-113.

37. Davis, J. R. (2006). Evaluating and Disseminating Experiences in Local Economic Development. $O b$ servations on Integrated Development Programmes of the Free DBSA (2009), DBSA Vulindlela Academy. Available at www.dbsa.org/Vulindlela. Accessed on 6 March, 2009.

38. Desse, F. (2012). The Role and Structure of Civil Society Organizations in National and Global Governance Evolution and Outlook between Now and 2030. Working Paper.

39. AUGUR Challenges for Europe in the world in 2030. Project no. SSH-CT-2009-244565 Collaborative Project. Available at: http://www.augurproject.eu/IMG/pdf/cso_note_provisional_draft5_june_2012.pdf. Accessed on 14 July, 2017.

40. Economic Development Department (2011). The New Growth path Framework. Available at: http://www.economic.gov.za/communications/51-publications/151-the-new- growth-path-framework.

41. Economic Development Partnership (2016). The practice of partnering for development. Lessons for University. City Building Presentation to Ford Foundation/HSRC Workshop. http://www.wcedp.co.za/Media/Default/Attachments/University-City_building-A-partneringapproach.pdf.

42. Edigheji, O. (2003). State-Society Relations in Post-Apartheid South Africa: The Challenges of Globalisation on Co-Operative Governance. In Guy Mhone and Omano Edigheji (eds.). Governance in the New South Africa: The Challenges of Globalisation, Cape Town. University of Cape Town Press.

43. Eggers, W. and Macmillan, P. (2013). The Social Revolution: How business, government and social enterprises are team up to solve society's toughest problems. Published by Deloitte Global Services Limited, Kindle edition.

44. Emerson, K., Nabatchi, T., and Balogh, S. (2012). An integrative framework for collaborative governance. Journal of Public Administration Research and Theory, 22(1), 1-29.

45. Essia, U. (2015). Civil Society Organization - Public-Private Partnership in Cameroon: Review of possible Models, Challenges and Prospects. Pan African Institute for Development - West Africa (PAIDWA), Buea-Cameroun.

46. Fedorowicz, Jane, Gogan, Janis, L., Williams, Christine B. (2007). A collaborative network for first responders: Lessons from the Cap WIN case. Government Information Quarterly, 24, 785-807.

47. Fisher, R., Ury, W., and Patton, B. (2011). Getting to Yes: Negotiating Agreement Without Giving. In $2^{\text {nd }}$ Edition. Random House Business Book. MA. Available at http://www.fd.unl.pt/docentes_docs/ma/AGON_MA_25849.pdf.

48. Fishkin, J. (2009). When the People Speak. Deliberative Democracy and Public Consultation. New York: Oxford University Press.

49. Freeman, J. (2011). Collaborative Governance in the Administrative State. UCLA Law Review, 45(1), Available at: https://papers.ssrn.com/sol3/Data_Integrity_Notice.cfm?abid=11408.

50. Friedman, A. L. and Miles, S. (2002). Developing stakeholder theory. Journal of Management Studies, $39(1), 1-21$.

51. Fung, Archon and Erik Olin Wright (2001). Deepening Democracy: Innovations in Empowered Participatory Governance. Politics \& Society, 29(1), 5-41. 
52. Galli, Anya M. and Fisher, Dana R. (2016). Hybrid Arrangements as a form of Ecological Modernization: the Case of the US Energy Efficiency Conservation Block Grants. Sustainability, 8(1).

53. Gilbert, A. (2002). Scan globally; reinvent locally: reflecting on the origins of South Africa's capital housing subsidy policy. Urban Studies, 39(10), 1911-1933.

54. Good Governance Learning Network (2008). Local democracy in action. Cape Town: GGLN.

55. Gordhan, P. (2010). The Role of the National Council of Provinces in Co-Operative Government and Intergovernmental Relations: Unlocking the Synergy for Collective Effort. Subject for Discussion. People's Assembly. Available at http://www.pa.org.za/hansard/2010/august/26/proceedings-of-the-national-councilof-provinces-2/the-role-of-the-national-council-of-provinces-in-c. Accessed on 28th September 2016.

56. Heikkila, Tanya, and Andrea K. Gerlak (2005). The formation of large-scale collaborative resource management institutions: Clarifying the roles of stakeholders, science, and institutions. Policy Studies Journal, 33, 583-612.

57. Hendriks, S. (2013). South Africa's National Development Plan and New Growth Path: Reflections on Policy Contradictions and Implications for Food Security. AEASA Presidential Address 2012 - 1 October 2012, Bloemfontein.

58. Hindson, D. and Vicente-Hindson, V. (2005). Whither LED in South Africa? A commentary on the Policy Guidelines for Implementing Local Economic Development in South Africa. Unpublished paper, $17 \mathrm{p}$.

59. Hofisi, C., Mbeba, R., Maredza, A., and Choga, I. (2013) Scoring Local Economic Development Goals in South Africa: Why Local Government is Failing to Score. Mediterranean Journal of Social Sciences, 4(13), 591-595.

60. HSRC (2003). Evaluation of Local Economic Development in the Free State Province. Study Undertaken for the Premier's Economic Advisory Council of Free State, November 2003.

61. Huxham, C. and Hibbert, P. (2008). Hit or myth? Stories of collaborative success. In: Collaborative governance: a new era of public policy in Australia? ANZSOG. University Printing Services, ANU, Australia, pp. 45-50. ISBN 978-1-9215-3640-3.

62. ILO (2008). Local Economic Development Outlook 2008. Geneva. In Rogerson C. M. (2011). Africa: Global context and research directions, Development Southern Africa, 27(4), 465-480.

63. Imperial, Mark (2005). Using collaboration as a governance strategy: Lessons from six watershed management programs. Administration \& Society, 37, 281-320.

64. Innes, J. E., and Booher, D. E. (2010). Planning with Complexity: An Introduction to Collaborative Rationality for Public Policy. London and New York: Routledge.

65. Joeffe, H. (2015). The government cannot go it alone - but is it listening? Business Day Lives. Available at http://www.bdlive.co.za/opinion/2015/08/25/the-government-cannot-go-it-alone-- but-is-itlistening.

66. Kaiser, F. M. (2011). Interagency Collaborative Arrangements and Activities: Types, Rationales, Considerations. Congressional Research Service 7-5700, R41803. Available at https://www.fas.org/sgp/crs/misc/R41803.pdf, accessed on January 18, 2016.

67. Katz, C. (2004). Growing Up Global: Economic Restructurng and Children's Everyday Lives. Minneapolis, MN: University of Minnesota Press.

68. Koma, S. B. (2012). The Evolution of Developmental Local Government in South Africa: Issues, Trends and Options. Journal of US-China Public Administration, 9(1), 53-67.

69. Koppenjan, Joop, and Erik-Hans Klijn (2004). Managing uncertainty in networks: A network approach to problem solving and decision making. New York, NY: Routledge. In Emerson, K., Nabatchi, T., and Balogh, S. (2012). An integrative framework for collaborative governance. Journal of Public Administration Research and Theory, 22(1), 1-29.

70. Koschmann, M. A., Kuhn, T. R. and Pfarrer, M. D. (2012). A Communicative Framework of Value in Cross-Sector Partnerships. Academy of Management Review, 37(2), 332-354.

71. Lambshead, C. (2007). LED Policy and Support Units - Provincial Growth and Development Strategies: The case for updating and Strengthening the Influence of the DPL's National Guidelines. Unpublished Internal Report, DPLG, Pretoria.

72. Leck, H., and Simon, D. (2013). Fostering Multiscalar Collaboration and Co-operation for Effective Governance of Climate Change Adaptation. Urban Studies, 50(6), 1221-1238.

73. Legassick, M. (2010). The crisis of "service delivery". Delivery, 24, 48-49.

74. MacKinnon, D. and Derickson, K. D. (2012). From resilience to resourcefulness: A critique of resilience policy and activism.

75. Maserumule, M. H. (2008). Framework for strengthening the capacity of municipalities in South Africa: A developmental local government perspective. Journal of Public Administration, 43(3.2). 
76. Meyer, D. F. (2014). Local government's role in the creation of an enabling developmental environment. Administratio Publica, 22(1), 24-46.

77. Meyer-Stamer, J. (2003). Principles of LED: Options for South Africa. Community Self Reliance, 3, 1-4.

78. Montigoe, R. S. (2012). Monitoring and evaluation system utilisation for municipal support. PhD dissertation in public management and governance. North West University. South Africa

79. Moyo, T. (2007). Leadership Challenges for Successful Local Economic Development in South Africa. Journal of Public Administration, 42(3).

80. Murdock, Barbara, Carol Wiessner, and Ken Sexton (2005). Stakeholder participation in voluntary environmental agreements: Analysis of 10 Project XL case studies. Science, Technology \& Human Values $30: 223-250$.

81. National planning Commission (2011). National Development Plan. Pretoria. Government Printer

82. Narsiah, S. (2002). Neoliberalism and privatisation in South Africa. GeoJournal, 57(1), 3-13. Nel, E. (2001). Local Economic Development: An Assessment of its current status in South Africa. Urban Studies, 38(7), 1003-1024.

83. Nel, E. and Rogerson, C. M. (eds.). (2005). Local Economic Development in the Developing World: The Experience of Southern Africa. New Brunswick NJ and London, Transaction Press.

84. Nel, E. and Rogerson, C. M., (2003). Phase 1: Research on framework conditions for local economic development and case studies of selected local economies in South Africa as well as international models and state of the art practices regarding local economic development. Report commissioned by the DBSA, KfW, DPLG, Pretoria.

85. Nelana, B. (2005). Co-operative governance in integrated development planning - Local economic development in the Eastern Cape. Unpublished MPHIL dissertation, University of Stellenbosch. South Africa.

86. O'Leary, R. Nabatchi, T and Bingham, L. B. (2004). Environmental Conflict Resolution. In: Durant, D. Fiorino, \& R. O'Leary (eds.). Building Common Purpose: Challenges, Choices, and Opportunities for Environmental Governance in the 21st Century, 323-354. Cambridge, MA: MIT Press.

87. Ostrom, E. (1990). Governing the commons: The evolution of institutions for collective action. Cambridge: Cambridge University Press. In Emerson, K., Nabatchi, T., and Balogh, S. (2012). In integrative framework for Collaborative Governance. Journal of Public Administration Research and Theory, 22(1), 1-29.

88. Pape, M., Fairbrother, P., and Snell, D. (2016). Beyond the State: Shaping Governance and Development Policy in an Australian Region. Journal of Regional Studies, 50(5), 901-921. Available at http://dx.doi.org/10.1080/00343404.2015.1055461. Accessed on 26 September, 2016.

89. Patterson, C. (2008). Country Report on Local Economic Development in South. Unpublished Report prepared for GTZ Strengthening Local Governance Programme in South Africa, Pretoria.

90. Phillips, C. (2014). Partnership lessons from the One Cape Data project. Western Cape Economic Development Partnership (EDP). Series 4. Available at http://www.wcedp.co.za/Media/Default/pex/Case_study_One_Cape.pdf.

91. Provan, K. G., and Kenis, P. (2008). Modes of Network Governance: Structure, Management, and Effectiveness. Journal of Public Administration Research and Theory, 18(2), 229-252.

92. Purdy, J. M. (2012). A Framework for Assessing Power in Collaborative Governance Processes. Public Administration Review, 72(3), 409-417.

93. Republic of South Africa (RSA) (1996). Constitution of the Republic of South Africa, Act 108 of 1996. Government Gazette, 378. Pretoria: Government Printer.

94. Rodriguez-Pose, A. (2008). Milestones and challenges of LED practice and academic research, 5, 22-24.

95. Rogerson, C. M. (2011). Local economic development in sub-Saharan Africa: Defining potential roles for national government. African Journal of Business Management, 5(30), 11756-11767. Available at http://www.academicjournals.org/AJBM.

96. Rogerson, C. M. (2009). Strategic reviews of local economic development in South Africa. GTZ and DPLG: Pretoria.

97. Rogerson, C.M. (2011). Tracking Local Economic Development Policy and Practice in South Africa, 1994-2009. Accessed online from www.springerlink.com/index/.

98. Rogerson, C. M. and Rogerson, J. M. (2010). Tracking Local Economic Development Policy and Practice in South Africa, 1994-2009. Urban Forum, 22(2), 149-168. Accessed 27 April 2013.

99. RSA (2000). Municipal System Acts.

100.RSA (2010). The Role of the National Council of Provinces in Co-Operative Government And Intergovernmental Relations: Unlocking The Synergy For Collective Effort (Subject For Discussion). 
101. SALGA (2012). Proceedings of the National Council of Provinces. Appropriation Bill (Policy debate. People's Assembly). Available at http://www.pa.org.za/speech/466142. Accessed on 26th September 2016.

102. Selmeczi, A. (2015). Haunted by the rebellion of the poor: Civil society and the racialised problem of the (non-) economic subject. Faucault Studies, 20, 52-75.

103.Selsky J. W., Parker B. (2005). Cross-Sector Partnerships to Address Social Issues: Challenges to Theory and Practice. Journal of Management, 31(6), 1-25. Available at http://dx.doi.org/10.1177/0149206305279601.

104.Simmie, J. and Martin, R. (2010). The economic resilience of regions: Towards an evolutionary approach. Cambridge Journal of Regions, Economy and Society, 3, 27-44.

105.Smith, L. and Vawda, A. (2003). Citizen vs. Customer: Different Approaches to Public Participation in Service Delivery in Cape Town. Urban Forum, 14(1), 26-52.

106.Swartbooi, N. (2010). The Role of the National Council of Provinces In Co-Operative Government And Intergovernmental Relations: Unlocking The Synergy For Collective Effort (Subject For Discussion. People's Assembly. Available at http://www.pa.org.za/hansard/2010/august/26/proceedings-ofthe-national-council-of-provinces-2/the-role-of-the-national-council-of-provinces-in-c. Accessed on 28th September 2016.

107.Thomson, A. M., and Perry, J. (2006). Collaboration processes: Inside the black box. Public Administration Review, 66, 20-32.

108.Tomlinson, P. R. and Branston, J. R. (2016). Determinants of Firm Influence in Local Economic Governance and Development: Evidence from Two British Industrial Districts. School of Management, University of Bath, UK.

109.Torres, L. H. (2003). Deliberative Democracy: A Survey of the Field. A Report Prepared for the William and Flora Hewlett Foundation. Washington, DC: America Speaks.

110.Trah, G. (2005). Local Economic Development in South Africa: Addressing the Challenges. Bonn: GTZ. Available at http://led.co.za/sites/led.co.za/files/documents/52.pdf.

111.Turok, I. (2010). Towards a developmental state? Provincial economic policy in South Africa. Development Southern Africa, 27(4), 497-515. Available at http://dx.doi.org/10.1080/ 0376835X.2010.508582.

112.Visser, W. (2004). Shifting RDP into GEAR: The ANC Government's Dilemma in Providing an Equitable System of Social Security for the "New" South Africa. Paper Presented at the 40th ITH Linzer Konferenz [online]. Accessed on 15 October 2013.

113. South African History Online. Trevor Manuel unveils GEAR, From: South African History Online. Available at http://www.sahistory.org.za/dated-event/trevor-manuel-unveils-gear. Accessed at 4 November 2013.

114.Williamson, A. (2004). Mapping Public Deliberation. Cambridge, MA: John F. Kennedy School of Government.

115.Wolfe, D. A. (2010). The strategic management of core cities: Path dependence and economic adjustment in resilient regions. Cambridge Journal of Regions, Economy and Society, 3, 139-152.

116.World Bank (2012). Local Economic Development Quick Reference Guide, Urban Development Unit. The World Bank, Washington, DC. Available at http:/www.worldbank.org/urban/ led/led_pamphlet.pdf.

117.World Bank (2003). Local Economic Development: Quick Reference. Urban Development World Bank. Washington, D.C. World Bank, Washington, D.C.

118. Yamak and Suer (2005). State as Stackholder. Coporate Governance, 5, 111-120.

119.Zurba, M. (2014). Levelling the Playing Field: Fostering Collaborative Governance towards On-Going Reconciliation. Environmental Policy and Governance. Environmental Policy Governance, 24, 134-146. 


\section{Appendix}

\begin{tabular}{|c|c|c|c|c|c|}
\hline & & State & Private sector & $\begin{array}{l}\text { Civil society } \\
\text { organization }\end{array}$ & Accountability enhancer \\
\hline \multicolumn{2}{|c|}{ Resources } & - $\quad$ Public funds. & $\begin{array}{l}\text { Corporate } \\
\text { social responsi- } \\
\text { bility/ } \\
\text { donations/ } \\
\text { contributions. }\end{array}$ & $\begin{array}{l}\text { Contribu- } \\
\text { tions/donations. }\end{array}$ & $\begin{array}{l}\text { - Rewards and incentive } \\
\text { system in place. }\end{array}$ \\
\hline \multicolumn{2}{|c|}{ Legal framework } & $\begin{array}{l}\text { - Setting the } \\
\text { agenda; } \\
\text { Outcome ex- } \\
\text { pectations for } \\
\text { the process. }\end{array}$ & $\begin{array}{l}\text { - } \\
\text { Participate in } \\
\text { setting common } \\
\text { agenda; } \\
\text { Make input } \\
\text { contributions on } \\
\text { investments and } \\
\text { economic } \\
\text { growth. }\end{array}$ & $\begin{array}{l}\text { Participate in set- } \\
\text { ting social devel- } \\
\text { opment goals; } \\
\text { - Make input contri- } \\
\text { butions; } \\
\text { - Sensitize and mobi- } \\
\text { lize the public. }\end{array}$ & $\begin{array}{l}\text { - Clarity of laws and } \\
\text { regulations; } \\
\text { Institutional arrange- } \\
\text { ment. }\end{array}$ \\
\hline \multirow{3}{*}{$\begin{array}{l}\text { Process } \\
\text { elements }\end{array}$} & $\begin{array}{l}\text { Partici- } \\
\text { pants/ rep- } \\
\text { resentation }\end{array}$ & $\begin{array}{l}\text { - Selection of } \\
\text { participants; } \\
\text { Limits on par- } \\
\text { ticipants. }\end{array}$ & $\begin{array}{l}\text { Participate to } \\
\text { select partici- } \\
\text { pants and to de- } \\
\text { termine limits } \\
\text { of participants. }\end{array}$ & $\begin{array}{l}\text { - Sensitize and mobi- } \\
\text { lize public partici- } \\
\text { pation. }\end{array}$ & $\begin{array}{l}\text { Transparency of deci- } \\
\text { sion making; } \\
\text { Democracy of deci- } \\
\text { sion making process; } \\
\text { Effort to communicate } \\
\text { with stakeholders in } \\
\text { decision making. }\end{array}$ \\
\hline & $\begin{array}{l}\text { Process } \\
\text { design }\end{array}$ & $\begin{array}{l}\text { - } \begin{array}{l}\text { Ownership of } \\
\text { the process; }\end{array} \\
\text { Interaction } \\
\text { expectations for } \\
\text { the process; } \\
\text { - } \quad \text { Number, length } \\
\text { and location of } \\
\text { meetings. }\end{array}$ & $\begin{array}{l}\text { Co-ownership } \\
\text { of the process; } \\
\text { Setting com- } \\
\text { mon agenda on } \\
\text { the numbers, } \\
\text { length and loca- } \\
\text { tions of meet- } \\
\text { ings. }\end{array}$ & $\begin{array}{l}\text { - Co-ownership of } \\
\text { the process; } \\
\text { - Setting common } \\
\text { agenda on the } \\
\text { numbers, length } \\
\text { and locations of } \\
\text { meetings. }\end{array}$ & $\begin{array}{l}\text { - Clear description of } \\
\text { tasks and responsibility; } \\
\text { Expertise of repre- } \\
\text { sentative. }\end{array}$ \\
\hline & Content & $\begin{array}{l}\text { - } \\
\text { agetting the } \\
\text { - } \quad \text { Outcome and } \\
\text { expectations for } \\
\text { the process. }\end{array}$ & $\begin{array}{l}\text { Participate in } \\
\text { setting goals on } \\
\text { investments and } \\
\text { macro- } \\
\text { economic } \\
\text { growth and sus- } \\
\text { tainability. }\end{array}$ & $\begin{array}{l}\text { Participate in set- } \\
\text { ting goals on ad- } \\
\text { dressing social is- } \\
\text { sues of crimes, un- } \\
\text { employment and } \\
\text { poverty providing } \\
\text { input to agenda- } \\
\text { setting and policy } \\
\text { development pro- } \\
\text { cesses. }\end{array}$ & $\begin{array}{l}\text { - } \quad \text { Clear description of } \\
\text { tasks and responsibility; } \\
\text { Expertise of repre- } \\
\text { sentative. }\end{array}$ \\
\hline
\end{tabular}

Table 1. Roles of stakeholders in a hybrid powered collaborative governance 